No 4078

Studia nad Autorytaryzmem i Totalitaryzmem 43, nr 4

Wrocław 2021

https://doi.org/10.19195/2300-7249.43.4.27

\author{
MICHAŁ BŁACHUT \\ ORCID: 0000-0001-8084-7030 \\ Uniwersytet Wrocławski \\ michal.blachut@uwr.edu.pl
}

\title{
Kryzys idei neutralności moralnej prawa
}

Słowa kluczowe: neutralność moralna prawa, liberalizm, praktyki totalitarne.

\author{
THE CRISIS OF THE IDEA OF THE MORAL NEUTRALITY OF LAW
}

\begin{abstract}
The idea of the moral neutrality of law is a characteristic element of liberal political and legal doctrines. This concept is also an element of constitutional principles regulating the limits of permissible legislative interference in the sphere of freedom. In such context, the bond linking it with the clearly defined axiology from which it derives is severed. The aim of this study is to consider to what extent the principle of the moral neutrality of law, being a principle affecting the activity of the legislator, retains its potential in identifying and limiting totalizing practices aimed at systematically limiting choices in the field of the concept of a good life and favouring a specific vision of the legal and political order in both spheres of human activity, individual and collective. The numerous variants of the moral neutrality of law formulated in political philosophy, and the distinctions between individual variants, in conjunction with the criticism of this concept, make it necessary to pay attention to whether this way of limiting totalizing practices is a good tool, resistant to the changing conditions. A review of critical arguments directed against the idea of neutrality leads to the conclusion that the weakening of the concept of the moral neutrality of law translates not only into its value in identifying and preventing totalizing practices, but also into weakening the protection of fundamental values, such as individual autonomy.
\end{abstract}

Keywords: moral neutrality of law, liberalism, totalitarian practices.

Idea neutralności moralnej prawa to trwały składnik współczesnych liberalnych koncepcji państwa i prawa. $Z$ jednej strony stanowi ona przedmiot praktyk usprawiedliwiających jej słuszność, z drugiej zaś jej funkcją jest legitymowanie określonych sposobów społecznej koegzystencji jako zgodnych z wartościami 
liberalnymi (autonomia jednostki, równość), a jednocześnie przynoszących członkom wspólnoty rozliczne korzyści płynące z uwzględnienia tej idei w konstruowaniu porządku prawnego. Jednym z aspektów tej idei jest zabezpieczenie jednostki przed praktykami totalizującymi, opartymi na uprzywilejowaniu epistemologicznym prawodawcy i zatarciu granicy pomiędzy moralnością prywatną a publiczną. Wspólną cechą tych praktyk, właściwych różnym wariantom totalitaryzmu, jest bowiem monopol poznawczy ośrodka władzy w zakresie moralności zarówno jednostkowej, jak i publicznej. W tym aspekcie koncepcja neutralności wydaje się głosem stanowczego sprzeciwu wobec takich praktyk: ogranicza tytuł władzy publicznej do faworyzowania określonych koncepcji moralnych oraz żąda respektowania granicy pomiędzy moralnością prywatną a publiczną.

Potencjał idei neutralności miał dostarczać z jednej strony narzędzi tamujących praktyki moralizujące lub paternalistyczne, a z drugiej strony — instrumentów zdolnych rozpoznawać zagrożenia dominacji określonej koncepcji dobrego życia. Wiele wskazuje jednak na to, że koncepcja neutralności moralnej prawa została skrojona na okoliczności, które nie stanowią dla niej wymagających warunków stosowania. W sytuacji kryzysu lub zagrożenia nie dostarcza ona zaplecza pozwalającego bronić wartości, na których się wspiera. Inaczej rzecz ujmując: jedynie afirmacja określonego zestawu wartości pozwala bronić zastosowania koncepcji neutralności moralnej prawa i dyskutować nad jej zastosowaniem. Kryzys w zakresie akceptacji podstaw aksjologicznych pozbawia koncepcję neutralności przypisywanych jej zalet. Warto więc postawić pytanie, czy podatność idei neutralności moralnej prawa na konsekwencje niesprzyjających jej warunków pozwala mówić w ogóle o jakimkolwiek jej samoistnym znaczeniu w ochronie przed totalizującymi praktykami, w zakresie zarówno normatywnym, jak i wyjaśniającym. W związku z tym należy zwrócić uwagę na rdzeń koncepcji neutralności oraz łączony $\mathrm{z}$ nim zestaw problemów. To da podstawy do sformułowania tezy, że koncepcja neutralności moralnej prawa nie ma wystarczającego potencjału zarówno w warstwie wyjaśniającej (czyli identyfikacji i wyjaśniania zagrożeń pochodnych od praktyk totalizujących), jak i perswazyjno-argumentacyjnej czy też normatywnej (to jest stawiania zapory praktykom totalizującym). Przedmiotem zainteresowania jest tu neutralność moralna prawa nie tylko jako element określonej doktryny prawno-politycznej, lecz także jako zasada regulująca aktywność prawodawczą w jakimś sensie oderwana od sprecyzowanej aksjologii.

Tytułem wprowadzenia zwrócić należy uwagę, że „neutralność prawa” to termin używany w dyskusjach nad stosunkiem prawa do wartości moralnych, koncepcji dobrego życia itp., będących zazwyczaj składnikami rozmaitych doktryn moralnych, religijnych, filozoficznych. Treści przypisywane temu terminowi łączy się dodatkowo z takim terminami, jak „tolerancja”, „bezstronność” czy „sprawiedliwość”. Właściwy dla niniejszego opracowania sens neutralności prawa można uchwycić, odwołując się do trzech kontekstów użycia terminu „neutralność prawa”. 
Pierwszy z tych kontekstów odwołuje się do zaangażowania prawa $\mathrm{w}$ regulowanie zachowań, które z perspektywy różnych stanowisk moralnych mogą być naznaczane aprobatą, dezaprobatą lub mogą być uznawane $\mathrm{z}$ ich punktu widzenia za obojętne. W tym sensie prawo nie może być wolne od aksjologicznych uwikłań, a co za tym idzie, nie może być moralnie neutralne ${ }^{1}$. Drugi z kontekstów odwołuje się do relacji obowiązywania łączącej prawo i moralność. Nie chodzi w tym przypadku o sam fakt zaangażowania prawa w regulowanie zachowań moralnie doniosłych, ale o to, czy stan zgodności/niezgodności z zewnętrznym systemem normatywnym, na przykład moralnym, legitymuje obowiązywanie prawa. Trzeci z kontekstów to ten właściwy dla rozważanych tu kwestii. W jego ramach to neutralność moralna prawa jest rodzajem postulatu wobec prawa albo zasadą porządkującą działanie prawa $\mathrm{w}$ zakresie stosunku prawa do różnorodnych stylów życia funkcjonujących w obrębie społeczeństwa w sposób, który gwarantuje pokojową koegzystencję możliwie jak największej ich liczby. Stan taki ma być rezultatem powstrzymania się państwa od ustanawiania regulacji preferujących taką czy inną doktrynę moralną. Tak rozumiana idea neutralności moralnej prawa wywodzi się z filozofii liberalnej, redukującej rolę państwa (w tym przypadku w zakresie formułowania ocen moralnych) oraz promującej wolność jednostki. Postulat czy zasada neutralności są najczęściej odnoszone do procesu tworzenia prawa i w bardzo metaforycznym sensie oznaczają sytuację, w której prawodawca przy podejmowaniu decyzji bierze w nawias poglądy moralne (styl, koncepcje życia) adresatów prawa i w swych decyzjach kieruje się jedynie ochroną wolności ${ }^{2}$.

Zwrócić należy również uwagę na dwa warianty legitymowania koncepcji neutralności moralnej prawa: jeden oparty na racjach zasadniczych, drugi - na pragmatycznych. Jeśli chodzi o te pierwsze, to główną rolę $\mathrm{w}$ ich przypadku odgrywają dwie idee: wolności i równości oraz odrzucenie poznawczego uprzywilejowania państwa wyrażające się w hasłach antypaternalizmu i antymorali$\mathrm{zmu}^{3}$. Racje te zbieżne są $\mathrm{z}$ katalogiem wartości wyznawanych przez doktryny liberalne. Racje pragmatyczne z kolei porzucają konieczność oparcia koncepcji neutralnego moralnie prawa na jakiejś metafizyce na rzecz akcentowania praktycznych korzyści płynących z przyjęcia tej koncepcji. Inaczej mówiąc: racje

1 Zob. J. Nowacki, Problem moralnej indyferentności przepisów prawa pozytywnego, „Zeszyty Naukowe Uniwersytetu Łódzkiego. Seria I. Nauki Humanistyczno-Społeczne” 1996, z. 47, s. 212 n.; Z. Ziembiński, Wstęp do aksjologii dla prawników, Warszawa 1990.

2 Zob. W. Sadurski, Neutralność moralna prawa (Przyczynek do teorii prawa liberalnego), „Państwo i Prawo” 1990, z. 7, s. 28; T. Pietrzykowski, Z. Tobor, Postulat neutralności w porzadku prawnym, [w:] System prawny a porzadek prawny, red. O. Bogucki, S. Czepita, Szczecin 2008, s. 179.

${ }^{3}$ H. Häyry, Legal Paternalism and Legal Moralism: Devlin, Hart and Ten, „Ratio Juris” 5 , 1992, nr 2, s. 191 i 194-197; szerzej zob. T. Pietrzykowski, Etyczne problemy prawa. Zarys wykta$d u$, Katowice 2005, s. 115 n. 
te nie wymagają oparcia $\mathrm{w}$ jakiejś filozoficznej prawdzie, ale koncentrują się na podkreśleniu realnych zalet objawiających się w społecznej praktyce ${ }^{4}$.

Bardziej szczegółowe analizy wskazują, że neutralność moralna prawa w tym właściwym dla liberalizmu sensie - może występować w przynajmniej jednym z czterech podstawowych znaczen ${ }^{5}$. Po pierwsze, jako neutralność szans, zgodnie z którą instytucje prawne powinny pozwolić zaistnieć wszystkim stylom życia. Po drugie, jako neutralność rezultatów. W tym przypadku polityka tworzenia prawa ma prowadzić do takich rezultatów, które nie faworyzują jednych stylów życia i nie szkodzą innym. W trzecim znaczeniu neutralność moralna prawa pojawia się jako neutralność proceduralna i sprowadza się do zakazu uzasadniania decyzji politycznych poprzez odwołanie się do poglądu, iż pewne style życia są lepsze od innych. Z kolei zgodnie z czwartym znaczeniem - neutralnością celu - państwo nie powinno wspierać pewnych koncepcji dobrego życia w stopniu większym niż inne ${ }^{6}$.

Dwa z pierwszych sposobów rozumienia neutralności moralnej prawa (neutralność szans i neutralność rezultatów) zdają się niemożliwe do urzeczywistnienia w praktyce. Natomiast różnica pomiędzy dwiema ostatnimi wersjami neutralności może być trudna do uchwycenia. Można powiedzieć, że zachowanie neutralności celu jest możliwe nawet w przypadku, kiedy państwo faworyzuje pewien styl życia czy też światopogląd, argumentując, że styl ten czy też światopogląd sprzyja pokojowej egzystencji możliwie jak najszerszej palety koncepcji dobrego życia. Mogłoby tak być na przykład, gdyby państwo udzielało wsparcia religii głoszącej postawę tolerancji wobec odmiennych przekonań. Z kolei zasada neutralności proceduralnej może być spełniona, nawet jeśli rzeczywiste rezultaty podjętej decyzji politycznej sprzyjać będą określonym stylom życia bardziej niż innym, bo najważniejszym elementem działania neutralnego jest motywacja towarzysząca działaniu prawodawcy, a ta musi być neutralna. Wobec faktycznego moralnego pluralizmu społeczeństwa tylko taka wersja neutralności - wedle jej zwolenników — jest możliwa do urzeczywistnienia. Neutralna procedura nie gwarantuje wcale nieneutralnych rezultatów, a wręcz zakłada, że pewne koncepcje życia, na przykład oparte na nienawiści do innych, zostaną postawione w gorszej sytuacji od innych koncepcji, na przykład takich, które oparte są na ideale tolerancji. $Z$ kolei neutralność biorąca pod uwagę rezultaty przyjętych rozwiązań wcale nie musi być przejawem neutralnej procedury podejmowania decyzji. W przypadku neutralności proceduralnej wyeliminowaniu ulegają czynniki, na

${ }^{4}$ Zob. R. Rorty, Obiektywność, relatywizm i prawda, przeł. J. Margański, Warszawa 1999, s. 312 .

5 Zob. W. Ciszewski, Zasada neutralności światopogladowej państwa, Kraków 2019, s. 125 n. Autor wyróżnia dwa typy koncepcji neutralności moralnej prawa: konsekwencjalistyczne i niekonsekwencjalistyczne i przyjmuje, że te pierwsze stanowią współcześnie właściwą ramę dla dyskusji o neutralności światopoglądowej państwa.

6 W.A. Galston, Cele liberalizmu, przeł. A. Pawelec, Kraków 1999, s. 117-119. 
które można się powołać w celu usprawiedliwienia decyzji politycznej. Podsumowując: postawa neutralna to taka, która polega — w przypadku ujęcia proceduralnego - na powstrzymaniu się od podejmowania decyzji prawodawczych wyłącznie ze względu na motywację głoszącą, iż pewne formy ludzkiej autokreacji są bardziej wartościowe od innych ${ }^{7}$. Dodać warto, że zachowanie postawy neutralnej nie oznacza wcale obowiązku powstrzymania się od podejmowania decyzji w sytuacji konfliktowej ${ }^{8}$. Taka też wersja neutralności moralnej prawa dominuje w liberalnej filozofii, choćby w koncepcjach J. Rawlsa, R. Dworkina czy W. Sadurskiego.

Jakkolwiek struktura działania tak pojmowanej neutralności moralnej jest w miarę czytelna, to problemy pojawiają się w momencie prób odróżniania motywacji neutralnych od nieneutralnych. Pierwszy problem dotyczy samego sposobu rekonstruowania intencji prawodawcy, drugi zaś - kryterium, za pomocą którego można odróżniać motywacje neutralne od nieneutralnych. Pierwszy ma charakter wykraczający poza podejmowane tu kwestie i nie doczekał się w prawoznawstwie zadowalającego rozwiązania. Drugi problem wynika z tego, że postulat neutralności moralnej prawa zmusza do podania takiego uzasadnienia decyzji ograniczającej czyjąś wolność, aby podjęcie tej decyzji nie mogło być odczytane jako wyraz preferencji dla tych, których wolność się chroni, a dezaprobaty dla tych, których wolność się ogranicza.

Kryteriów pozwalających na odróżnianie motywacji neutralnych od nieneutralnych wedle niektórych ujęć dostarczać może sformułowana przez J.S. Milla zasada krzywdy. Zgodnie z nią

\begin{abstract}
jedynym celem usprawiedliwiającym ograniczenie przez ludzkość, indywidualnie lub zbiorowo, swobody działania jakiegokolwiek człowieka jest samoobrona, że jedynym celem, dla którego ma się prawo sprawować władzę nad członkiem cywilizowanej społeczności wbrew jego woli, jest zapobieżenie krzywdzie innych. Jego własne dobro, fizyczne lub moralne, nie jest wystarczającym usprawiedliwieniem. Nie można go zmusić do uczynienia lub zaniechania czegoś, ponieważ tak będzie dla niego lepiej, ponieważ zdaniem innych osób będzie to mądrym lub nawet słusznym postępkiem ${ }^{9}$.
\end{abstract}

W tym kontekście zakaz zabijania motywowany jest ochroną wolności, a nie dyskryminacją poglądów opartych na braku szacunku dla życia innych osób lub chęcią moralnej naprawy tych, których wolność się ogranicza ${ }^{10}$.

Jak widać przy przyjęciu tego kryterium kluczowe będzie zdefiniowanie pojęcia krzywdy, albowiem może być ono tak pojmowane, iż skrywać będzie za sobą na przykład preferencje dla określonych poglądów moralnych. Tym samym decyzje motywowane chęcią zapobieżenia krzywdzie mogą w sposób ukryty

${ }^{7}$ W. Sadurski, op. cit., s. 28 i 36.

8 T. Pietrzykowski, Z. Tobor, op. cit., s. 180.

9 J.S. Mill, O wolności, przeł. A. Kurlandzka, Warszawa 1999, s. 25; zob. też s. 71 i 111.

10 Zob. D. Bunikowski, Podstawowe kontrowersje dotyczace ingerencji prawa $w$ sferę moralności, Toruń 2010, s. 316. 
zakładać przyjęcie funkcjonujących w społeczeństwie kryteriów użycia pojęcia krzywdy. Tak zaś rozumiane pojęcie nie jest optymalnym kryterium wykluczania państwowego przymusu wspierającego dominującą moralność ${ }^{11}$. Podobne zagrożenia dostrzega K. Henley, który podkreśla, że pod płaszczykiem stosowania zasady krzywdy, jako utrzymującej stan pokojowej koegzystencji członków społeczeństwa, państwo może promować faworyzowaną wizję cennego sposobu życia $^{12}$. Zagrożenia takie pojawiają się zwłaszcza wtedy, gdy założenia koncepcji neutralnego moralnie prawa implementuje się $\mathrm{w}$ warunkach konkretnego społeczeństwa z konkretną historią i tradycją, społeczeństwa nasyconego stereotypami, uprzedzeniami ${ }^{13}$.

Inne kryteria, takie między innymi jak test wyłącznej motywacji ${ }^{14}$ czy też oparte na rozróżnieniu zachowań względem siebie i względem innych ${ }^{15}$, w mniejszym lub większym stopniu budzą zastrzeżenia charakterystyczne dla zasady krzywdy ${ }^{16}$. Jest tak dlatego, że niezależnie od przyjętego sposobu odróżniania tego, co neutralne, od tego, co nieneutralne, sposób ten będzie zawsze poprzedzony bardziej podstawowym rozstrzygnięciem aksjologicznym. A wskutek tego samo pochodzenie omawianego kryterium lub sposób jego stosowania nie będą moralnie sterylne. Koncepcja neutralności moralnej prawa zakłada bowiem zawsze, że pewien katalog podstawowych wartości zostaje przeniesiony ze sfery moralności do sfery prawa. Innymi słowy: koncepcja neutralności moralnej prawa zakłada istnienie takiego katalogu wartości, który stanowić musi konieczny składnik prawa i jest przez prawo chroniony lub wspierany. $Z$ jednej strony przesądza on o interpretacji zasady neutralności, z drugiej zaś jego ochrona bądź wspieranie nie są kwalifikowane jako działania nieneutralne. Przykład takich wartości włączonych do sfery prawa stanowia prawa człowieka albo przynajmniej fundamentalna preferencja dla jednostkowej autonomii. Tym samym to nie idea neutralności rozwiązuje samodzielnie problem odróżnienia motywacji neutralnych od nieneutralnych, lecz uprzednie rozstrzygnięcie o preferencji dla określonego systemu wartości. Znając te rozstrzygnięcia oraz treść zasady neutralności, można z większą skutecznością odróżniać prawo moralnie neutralne od prawa moralnie nieneutralnego, lecz za każdym razem będzie to neutralność z konkretnego punktu widzenia.

11 W. Sadurski, Moral Pluralism and Legal Neutrality, Dordrecht 1990, s. 99, 200.

12 K. Henley, Tolerance, Liberalism, Community. The Paideia Archive, Twentieth World Congress of Philosophy, http://www.bu.edu/wcp/Papers/Poli/PoliHenl.htm (dostęp: 20.07.2021).

13 Problemy takie w warunkach polskiego społeczeństwa interesująco przedstawia W. Brzozowski, Bezstronność światopogladowa władz publicznych w Konstytucji RP, Warszawa 2011.

14 Zob. W. Sadurski, Neutralność..., s. 36.

15 H.L.A. Hart, Law, Liberty, and Morality, London 1963, s. 5.

16 Szerzej przypadki i kryteria ingerencji prawa w sferę moralności omawia D. Bunikowski, op. cit. 


\section{$* * *$}

Podsumowując: pojęcie neutralności moralnej prawa - niejako oderwane od swojego zaplecza aksjologicznego - nie pozwala na odróżnianie prawa moralnie neutralnego od prawa zorientowanego na dominację określonej wizji dobrego życia lub na daleko posuniętą ingerencję w sferę objętą autonomią jednostki. Innymi słowy: nierzadko koncepcje neutralności moralnej prawa, budowane z dbałością o detale dotyczące dystynkcji pomiędzy neutralnością celów, szans czy motywacji, zdają się pełnić funkcję racjonalizującą uprzednio dokonane wybory aksjologiczne, aniżeli stanowić samoistne narzędzie identyfikacji praktyk totalizujących. W tym kontekście koncepcja neutralności moralnej może być nawet zredukowana do funkcji retorycznej, optymalizującej projektowaną wizję określonego porząaku społecznego.

Krytyka idei neutralności moralnej prawa prowadzona jest na różnych poziomach. Na poziomie uzasadnienia krytyka taka nie różni się w zasadzie od samej krytyki doktryny liberalnej. Na poziomie operacyjności zasady neutralności wykazuje się różne usterki uniemożliwiające jej sprawne stosowanie, a to między innymi przez nie zawsze dostatecznie doprecyzowaną treść tej zasady oraz użycie kryteriów wymagających wartościowania. Bardziej fundamentalna krytyka mogłaby głosić, że zasada neutralności nie dostarcza wcale sposobu na podejmowanie neutralnych decyzji, za to umożliwia zneutralizowanie zapadłych już, nieneutralnych, decyzji. Koncepcji tej wreszcie zarzuca się, że została zaprojektowana na potrzeby zachodniego, zindywidualizowanego i względnie homogenicznego kulturowo oraz moralnie społeczeństwa, którego w zasadzie już nie ma, a w warunkach wytwarzanych przez ponowoczesne społeczeństwa koncepcja neutralności moralnej prawa nie odnajduje się najlepiej. Jest tak, ponieważ współczesne społeczeństwa stają się coraz bardziej heterogeniczne kulturowo i moralnie (choćby w wyniku procesów globalizacyjnych i integracyjnych), a preferencje jednostek dla form organizacji życia, które byłyby wspólnotowe i jednocześnie oparte na konkretnym systemie wartości, nie są już rzadkością. Nadto wybory moralne jednostek nie polegają wyłącznie na wyborze gotowych systemów wartości, lecz obejmują swym zakresem także wartości przynależące do prima facie sprzecznych doktryn moralnych. Efekty działania koncepcji neutralności moralnej prawa bywają też coraz częściej odczytywane nie tyle jako konieczny skutek działań bezstronnego arbitra, który musi koordynować konkurujące ze sobą style życie, ile jako akt opresji, dominacji ze strony uprzywilejowanego światopoglądu liberalnego. W takim świetle zaś koncepcja neutralności moralnej prawa zajmuje pozycje, które na dobrą sprawę mogłaby sama krytykować. Nie jest wykluczone, że krytyka, często niemerytoryczna, która spada na koncepcję neutralnego moralnie prawa, obliczona jest na przerwanie najsłabszego ogniwa w łańcuchu 
legitymującym liberalne koncepcje prawa. Trzeba mieć również na uwadze, że podejmowane są stałe próby obrony i jednocześnie pewnej korekty idei neutralności moralnej prawa ${ }^{17}$, które rzeczowo dyskutują z podnoszonymi tu wątpliwościami. Niemniej jednak wydaje się, że aplikacja idei neutralności jako zasady limitującej aktywność prawodawczą nie zyska już pierwotnie zakładanej rangi.

\section{Bibliografia}

Brzozowski W., Bezstronność światopogladowa władz publicznych w Konstytucji RP, Warszawa 2011.

Bunikowski D., Podstawowe kontrowersje dotyczace ingerencji prawa w sferę moralności, Toruń 2010.

Ciszewski W., Zasada neutralności światopogladowej państwa, Kraków 2019.

Galston W.A., Cele liberalizmu, przeł. A. Pawelec, Kraków 1999.

Hart H.L.A., Law, Liberty, and Morality, London 1963.

Häyry H., Legal Paternalism and Legal Moralism: Devlin, Hart and Ten, „Ratio Juris” 5, 1992, nr 2.

Henley K., Tolerance, Liberalism, Community. The Paideia Archive, Twentieth World Congress of Philosophy, http://www.bu.edu/wcp/Papers/Poli/PoliHenl.htm.

Mill J.S., O wolności, przeł. A. Kurlandzka, Warszawa 1999.

Nowacki J., Problem moralnej indyferentności przepisów prawa pozytywnego, „Zeszyty Naukowe Uniwersytetu Łódzkiego. Seria I. Nauki Humanistyczno-Społeczne” 1996, z. 47.

Pietrzykowski T., Etyczne problemy prawa. Zarys wyktadu, Katowice 2005.

Pietrzykowski T., Tobor Z. Postulat neutralności w porzadku prawnym, [w:] System prawny a porzadek prawny, red. O. Bogucki, S. Czepita, Szczecin 2008.

Rorty R., Obiektywność, relatywizm, prawda, przeł. J. Margański, Warszawa 1999.

Sadurski W., Moral Pluralism and Legal Neutrality, Dordrecht 1990.

Sadurski W., Neutralność moralna prawa (Przyczynek do teorii prawa liberalnego), „Państwo i Prawo" 1990, z. 7.

Ziembiński Z., Wstęp do aksjologii dla prawników, Warszawa 1990.

17 W. Ciszewski, op. cit., s. 287. 